\title{
A Feel for the Land
}

This fall another great horde of Canadians have returned to their homes after a summer camping holiday. These people have a new awareness about the forest land resource that dominates the Canadian landscape.

A great many of these summer travellers have not only seen the forest from the car windows but have camped in it night after night. Their contact with the forest has been intimate, often reinforced by nature walks and guided tours in National and Provincial Parks. To these people, large portions of Canada are no longer empty spaces on gasoline company maps, but instead they are filled by memories of a great diversity of forested camp and picnic sites. These people now have a feel for Canada's forests, they are now interested in decisions regarding their management.

To these people Canada's forests seem endless, wild, forbidding and occasionally magnificent. These people cannot help but appreciate the value of parks for recreation and preserva- tion of nature, they cannot avoid learning of the dangers of forest fires - this message hits them time and time again. However, there is an important impression that these people do not bring home with them in the fall - the message about the multiple benefits that can be produced by sound forest management.

The brutal visual shock of extensive clear cut areas which they repeatedly see, without explanation, can only lead to more public outcry against cutting. There is no law which insists that explanation, on the ground, be given to the public, but common sense indicates that violent changes in the landscape on pubic forests must be explained to the public.

As one of the horde of travelling Canadians last summer, I found nature tours, history tours, mine tours and mill tours - but no industrial or government forestry tours. If we as foresters, do not explain to the public what we are doing in public forests, then we will lose the privilege of working there.

G. F. Weetman.
Editor

G. F. Weetman 570 St. John's Rd., Pointe Claire, P.Q.

Associate Editors

Fire D. E. Williams

Forest Economics \& Policy D. V. Love

Forest Entomology

I. W. Varty

Forest Pathology G. Wallis
Forest Products

R. H. J. Creighton

Forest Management

G. F. Weetman

Logging

H. I. Winer

Silviculture

R. J. Day

D. Glew

Wildlife

D. H. Pimlott

French Associate Editors

M. Pineau

L. Parrot
Published bi-monthly by the Canadian Institute of Forestry - Institut Forestier du Canada. Address all correspondence concerning business matters to $A$. G. Racey, Secretary-Manager, P.0. Box 5000 , Macdonald College, P.Q., Canada. Subscription rates $\$ 10.00$ per year in Canada, $\$ 12.00$ in other countries. $\$ 2.50$

teed.

The Institute assumes no responsibility for the statements and opinions expressed by contributors. There is a $\$ 40$ per page charge for articles on the results of research. This charge is only made when the supporting agency has allocated funds for publication.

\section{드므}

Cover: X-Ray photos of seeds by R. J. Day. 